\title{
ON THE PROBLEM OF RENDERING RUDYARD KIPLING'S INDIVIDUAL STYLE IN TRANSLATION
}

\author{
Popeliuk Vyktoryia Pavlovna \\ Lecturer at the Department of Foreign Languages \\ Odesa Military Academy \\ Str. Fontanska Doroha, 10, Odesa, Ukraine
}

\begin{abstract}
The article is dedicated to the study of the translating specificity( R.Kipling's prose into Russian. The research is aimed at defining the peculiarities of Rudyard Kipling's individual style revealed in his famous literary tales.

The objective of the research is to outline possible difficulties in translating $R$. Kipling's tales and ways of overcoming those problems by employing translation techniques. The research is carried out on the basis of the original English tales and their translations into Russian. By means of comparative analysis the most adequate translation variants and successful techniques are selected. The main criteria of qualified translation are adequacy, faithfulness and equivalence.

The conclusion is drawn that the main strategies of translation are the strategy of the communicatively relevant translation and the translation of re-addressing. The main translation techniques at work, as it has been experimentally discovered, are correspondingly replacement and descriptive translation. The main challenges for translators have proved to be stylistic devices, occasional words, blends, as well as cases of sound-imitation and sequence of non-sequence. The original texts abound in the author's coinages, most of which were masterfully rendered by translators.

The quantitative parameters of the strategies distribution translation, tactics and techniques have revealed the typological commonness of the operations employed. There has been observed the correlation of the technique of de-metaphorization and the tactic of linguistic and cultural adaptation.

The perspective of the study of the variability of strategies, tactics and techniques in translating $R$. Kipling's prose into different languages is seen in researching the distinctive parameters of the translation strategies and tactics and in performing comparative analysis on the basis of other translation languages at work.

Key words: individual style, translation technique, adequacy, faithfulness, equivalence.
\end{abstract}

Introduction. R. Kipling's animalistic tales have often been in the focus of researchers' attention. Among the mostly recurrent aspects there were stylistic peculiarities of both lexical and syntactical levels, animalistic characters and the author's message. However, the novelty of the suggested research is in the focus on translation techniques aimed at rendering the author's individual style by means of Russian and Ukrainian.

Literary fairy-tales by H.Ch. Andersen, O. Wilde, R. Dahl, L. Carroll and R. Kipling as a unique subgenre distinguished from folk tales, were studied by many scholars, most of which specialized in their adequate translation, among them L. Skuratovskaya, N. Demurova, Ye. Dunaevskaya, L. Braude.

Problem-setting. All literary tales may be subdivided into the following groups: animalistic tales, fairy tales, cumulative tales, novelistic tales, nonsense. In this article we adhere to the definition of a functional style as a variety of literary language, associated with a certain area of social life, a genre is a group of literary works united by common features of form and content $[16,206]$. Separate styles are characterized by specific linguistic peculiarities, mostly, by vocabulary and syntactic structure of utterances while genres have inherent distinctive features both in form and content. [1,86].

The main genres distinguished by scholars are lyrical, dramatic and epic. Lyrical genres include epigram, madrigal, sonnet, epistle, ode, elegy and epitaph; dramatic- tragedy, comedy, drama; epic novel, ling short story, short story, novelette, feature article, tale, fable and parable [16, 208-255].

Tales have always aroused associations with literature for children as specially coined with reference to the psycho-age features of childhood. However, the vast majority of literary tales were aimed at adult readers.

The typological features of tales as a genre include the simplicity of the plot, the rigid structure, elements of adventure and mostly the happy end. Many tales are close to fables due to the moral they often contain either in the explicit or in the implicit form.

According to the Literary Encyclopedia all tales should be referred to folklore prose $[15,989]$. Protagonists are, as a rule, clearly distinguished as negative or positive personalities. The tale basis is often an antithesis of a dream and reality, which results in the complete but rather Utopian realization $[15,989]$. 
Among the tales typological features there should be mentioned such components as narration, orientation at entertainment, specific structure, sustainable poetics, a definite system of artistic devices which acquire poetic functions, gradation of a character's emotional state.

Many scholars distinguish between folklore, literary and author's fairy tales. A folklore fairy tale, according to the literary terms Dictionary, is "the epic folklore genre: prosaic oral narrative about the fictitious events in the folklore of different nations" [19]. Literary fairy tales originated from folklore ones, however, literary fairy tales are treated as a belles-lettres literary genre, since they always have an author or a group of authors. L. Braude in her article "To the history of the concept "literary fairy tale" "wrote that this work has both artistic and prosaic nature, and a literary fairy tale either is based on the folklore sources or it is completely invented by the author [2,234]. Such fairy tales have the author's message, individual concept, their texts are built in accordance with the specific plot-composition model. Literary fairy tales often reflect the historical period features, when their author lived, and his unique world view.

In contrast to literary fairy tales, which can borrow plots from folklore ones, author's fairy tales are "absolutely independent literary works with the original imaginary world and their specific aesthetical concept" $[19,148]$. The story, described in an author's fairy tale, is most often the author's idea and fruit of his ther imagination. An author's fairy tale is normally an extensive literary work with the large number of characters, events and plot lines $[18,106]$. It is possible to distinguish among the fairy-tale texts: the folklore fairy tale record (which can be word-for-word replica or a less complete version), a folklore fairy tale literary version and an author's fairy tale proper. In certain cases it is rather difficult to determine the clear boundary between the above mentioned types of fairy tales [19, 144].

Animalistic fairy tales are mostly allegoric. The characters are endowed with human features though they are not humans. In Kipling's animalistic fairy tales there are combined nature and civilization.

\section{Materials and Methods}

R. Kipling's under investigation included fairy tales collections "The Jungle Book", "The Second Jungle Book" and "Just so Stories" as well as their translations by Ye.Chistiakova-Ver, N. Daruzes, N. Giliarovskaia, K. Chukovskyi, L. Khavkina and V. Pozner[6,7,8,9,10,11,12].

The research objective is to analyze R. Kipling's fairy tales in the aspect of possible difficulties in rendering the author's individual style in translation and translation techniques allowing to overcome these difficulties.

Fairy tales in the collections "The Jungle Book" and "The Second Jungle Book" on the one hand, and "Just so Stories" on the other hand, were thoroughly analyzed in the aspect of their linguistic peculiarities on different levels. The fairy tales distinctive features under analysis include differences in lexis and syntax.

For example, all the fairy tales in the collection "Just so Stories" abound in dated words and expressions, diminutive words, contractions and lexical blends. All this was done in realization of the paronymic attraction stylistic technique employed by R. Kipling.

The language in the "The Jungle Book" and "The Second Jungle Book" adheres to Middle English. This is manifest in the usage of personal pronouns "ye", "thee" for "you" and possessive pronoun "thy" for "your", though "you" has been used in the literary style since XVIII. The following examples illustrate this tendency. "Ye may kill for yourselves, and your mates" $[19,31]$ "Must thou and I kill each other for yonder red-eyed slayer?" $[19,161]$ "...he shall hunt thee..." $[13,13]$. "Keep thy hand on my shoulder". [13, 87]

In verbal forms $3 \mathrm{~d}$ person singular the ending -st is preserved. Besides, the form "art" of the verb "to be" is used in the $2 \mathrm{~d}$ person singular and plural in the present tense and "wast" in the past tense, which is also characteristic of Middle English. For example, "Because thou wast my son..." [19, 72]; "thou art afraid of the Hairless One" [19, 23]. The forms "dost" and "canst" are used instead of "does" and "can". For example, "thou canst leap..." $[19,221]$. “...dost thou remember?" [19,72].

There also often occur archaic grammatical forms of interrogative pronoun "where" ("whither") as well as the dated varieties of deictic adverbs of place "here" ("hither") and "there" ('thither"). For example, "Now whither does this trail lead?" [19,211]; "I saw this light, and came hither." [19,260]; "If we can get thither to-night, we live. Otherwise we die." [19, 75]. Archaic conjunctions "ere" are also very recurrent. As in the following example: "Ere Mor the Peacock flutters..." $[19,163]$.

One of the distinctive features of R. Kipling's individual style is the employment of graphons, contractions and lexical blends in his fairy tales in the collection «Just so stories». Examples of shortenings: "satiable" instead of "insatiable", "scuse me" for "excuse me", " 'stute" for "astute", "scruciating" for "excruciating". Graphons or deliberately misspelled words may be illustrated by such lexical units as "hijjus" as corruption of "hideous", "curtiosity" instead of "curiosity", 
"dretful" as misspelled "dreadful", "a-purpose" instead of "on purpose".

There are deliberately made mistakes in the past tense forms like "creeped" instead of "crept", "lepped" instead of "leapt". And finally the deliberately erroneous spelling of the ordinal number "firstest" instead of "first". Such irregularities are very characteristic of children's speech and in such a way R. Kipling makes his fairy tales more comprehensive and accessible for children, by adapting their plot and language to the tastes and preferences of the younger ones.

R. Kipling also made use of many adjectives with suffix $-y$, thus narration acquired diminutive tonality and sounded more intimate. For example, such rhyming composites as "twirly-whirly", "snarly-yarly", "schloopy-sloshy", "slushysqushy", as well as other sound-imitating adjectives like "nubbly", "comfy", "musky", "tusky", "frouzly", and "tickly" allowed to create friendly and unofficial atmosphere. Some of them are nonce-words, coined by R. Kipling. The composite "twirly-whirly" was formed by uniting two verbal stems ("to twirl") and ("to whirl"), "nubbly" was coined on the basis of the verb "to nubble", while "snarly-yarly" was formed from the verb "to snarl" by adding an occasional words "yarly". Such lexical phenomena caused certain difficulties for adequately translating R. Kipling's unique prose.

To preserve the novelty and mock-seriousness of R. Kipling's individual narration style one of the main translators' work challenges in rendering the uniqueness of his prose is used with authenticity and high artistic value.

Another peculiarity of R. Kipling's literary fairy tales in the collection «Just so Stories» was his specific form of address to the reader -"Best Beloved". The author also often resorted to anadiplosis, inserting argumentation fragments in the narration. The recurrent phrases were also spotted, providing for the reader's full involvement in the plot events. For example, "Have you forgotten the suspenders?". That was a prompt sort that the fairy tales were aimed at being read aloud to the children by their parents.

\section{Results}

The overall linguistic analysis of R. Kipling's fairy tales aimed at distinguishing possible difficulties for translation revealed the following regularities. There were outlined about 93 stylistic devices on the phonetic level, 405 stylistic devices on the lexical level and 401 stylistic devices on the syntactic level. The most recurrent phonetic stylistic devices proved to be alliteration and onomatopoeia, among the lexical devices the most widely distributed there were epithets, metaphors and different types of lexical repetitions, finally, the prevailing syntactic stylistic devices included simile, parallelism, and polysyndeton. It should also be mentioned that phraseological units were widely employed by R. Kipling as well.

We assumed that the best way to study the R. Kipling's style peculiarities issue was in their successful rendering aspect in translation with the translation techniques frequency analysis at work.

Among the fairy tales collections translations selected for analysis "The Jungle Book" and "The Second Jungle Book" were the ones performed by Ye. Chistiakova-Ver, N. Daruzes and N. Giliarovska. The choice was grounded by the high accuracy and translation quality. All the translators were guided by the communicatively relevant translation strategy. The most recent translated versions majority, however, were performed in accordance with the re-addressing strategy and involved the original works' profound adaptation for children.

The collection "Just so Stories" translations analysis was carried out on the basis of the works by Ye. Chistiakova-Ver, K. Chukovskyi, L. Khavkina, V. Pozner, the latter being the most recent translation into Russian, dated 2015.However, V. Pozner translated only three fairy tales, namely: "The Elephant's Child", "The Cat that Walked by Himself" and "The Butterfly that Stamped".

The sample included 405 words and word combinations, selected from the above-mentioned stories collections, in particular 323 lexical and phraseological units from "The Jungle Book" and "The Second Jungle Book", 26 from the verses and 56 from the collection "Just so Stories".

The most widely distributed stylistic device is simile. In total there occurred about 131 similes in the fairy tales under investigation. All the translators succeeded in translation preserving simile which can be illustrated by the following examples.

R. Kipling: "...her eyes, like two green moons in the darkness..." [13, 10]. Ye. Chistiakova-Ver's translation:"...ее глаза, блестевиие в темноте как две зеленые луны..." [8,14]. N. Daruzes' translation: "...ее глаза, похожие во мраке на две зелёные луны..." [10,18]. N. Giliarovska's translation: "Ее глаза, как две зеленые луны в темную ночь". [7,13].

Ye. Chistiakova-Ver added expressiveness to the image by providing explicit grounding for translation, the participle "блестевшие" ("sparkling"). According to the Oxford's Dictionary of English, the first in recurrence meaning of the word "darkness" is "lack of light", while meaning "night" is considered secondary. N. Giliarovska's employed the translation explication technique by extending the notion of "darkness" to the 
descriptive word-combination "тёмная ночь" ("dark night"). N. Daruzes preserved the stylistic device by adding "похожие на" ("like").

On the phonographical level the most challenging devices for rendering in translation are spoonerism and graphons cases. Graphons are often predetermined by R. Kipling's intention to imitate speech defects or for rhyming and rhythmic purposes. For example, in order to show by means of the translation language the baby elephant's speech irregularities in the fairy tale "The Elephant's Child" K. Chukovskyi and P. Pozner found bright occasional phonetic equivalents.

R. Kipling: "Led go! You are hurtig be!" [19, 81]. К. Chukovskyi: "Пусдитебедя, бдеочедьбольдо!" [11,54]. P. Pozner: "Пусдиде! Бдебольдо" [12,15]. R. Kipling: "This is too butch for be!" [19,82].K. Chukovskyi: "Довольдо! Осдавьде! Я больше де богу!" [11, 55]. V. Pozner: "Нед сил, я больше де могу!" [12, 18].

However, not all R. Kipling's style peculiarities were successfully preserved. The archaic grammatical forms like "whither", "hither", "thither" were replaced with their modern semantic equivalents or even omitted in translation.

R. Kipling: "Ere Mor the Peacock flutters..." [55, 163].N. Giliarovskaya: "Мор Павлин еще спит..." [7, 320]. (omission). R. Kipling: "Now whither does this trail lead?" [19, 211]. Ye. Chistiakova-Ver: "Куда жеведет эта тропа?" $[8,336]$. (replacement).

Incertain cases the translator made concretization use. Like in this example. R. Kipling: "If we can get thither to-night, we live. Otherwise we die." $[19,75]$. Ye. Chistiakova-Ver: "Если мы в эту ночь доберемся до Кханивары, то останемся живы. Нет- умрем". [8, 230]. (concretization)

This is also true for the archaic forms of personal and possessive pronouns and auxiliary verbs. R. Kipling: “...thou canst leap...” [19, 221]. Ye. Chistiakova-Ver: "...ты можешь прыгнуть" [8,194]. N. Giliarovskaya: "...ты можешь прыгнуть..." [7,371]. (replacement).

R. Kipling: "thou art afraid of the Hairless One" $[19,23]$. Ye. Chistiakova-Ver: "...ты боишься Безшерстого". [8,192]. N. Giliarovskaya: "... ты сам боишься Безволосого" [7, 204]. (replacement).R. Kipling: "...dost thou remember? Because thou wast my son..." $[19,72]$. Ye. ChistiakovaVer: "...помнишь? Потому что ты мой сын..." [8, 227]. N. Giliarovskaya:"...ты помнишь, потому что ты мой сын..." [7, 245]. (replacement). At the same time the shortened form "scuse me" was translated by V. Pozner translated as "Звините".

All proper names in "The Jungle Book" were not invented by R. Kipling, but borrowed from
Hindi. Thus, "Bagheera" in Hindi means "panther", "Baloo" means "bear", "Hathi" means "elephant", "Shere Khan" means "The King of Tigers" and "Bandar-log" means "monkeys' nation".

It should be mentioned that "panther" in English is a masculine gender noun, while "пантера" in Russian is of feminine gender. So, in all the translations the main character is a graceful and cunning she-cat. This image has been greatly transformed and enriched with new nuances like beauty, gracefulness, wisdom, pride and wittiness. Bagheera in the English version is the antagonist of Shere Khan, a brave and powerful character. All this resulted in replacing "he", "him" and "his" with "она" ("she"), "еë" ("her").

Another distinctive feature of R. Kipling's style is the extensive interjections use. Some of these are very specific like "O, Bananas!" The closest translation variant might be "Вот это да!", expressing strong surprise, which in its turn is similar to "Oh My God!" or its shortened version "OMG".

R. Kipling: "Then he uncurled his trunk and knocked two of his dear brothers head over "O bananas!" said they, "where did you learn that trick, and what have you done to your nose?" $[19,86]$.

Ye.Chistiakova-Ver:"Tym он выпрямил свой хобот, ударил двоих из своих мильхх родственников, да так сильно, что они полетели кувырком.- Чудеса, - сказали они, - где ты выучился такой штуке?" [9, 215$].$ K. Chukovskyi: "И он развернул свой хобот, и тотчас же два его мильх братиа полетели от него вверх тормашками. - Клянёмся бананами! - закричали они. - Где это ты так навострился...?" [19, 62].

V. Pozner: "И он одним махом развернул хобот - и оба его мильх брата полетели вверх тормашками.- Ну и Бананы! - заревели они, где ты научился этому фокусу...?" [11, 23].

Epithets are also widely used by R. Kipling. It's a real challenge to render the emotional and imaginary value of epithets in translation.

The total epithets number amounted to 51 units. Among the epithets there were spotted simple epithets like "blazing eyes", "cheating moonlight"; complex epithets like "juicy-stemmed creepers", "clay-streaked heads"; trite epithets like "pure delight"; authentic author's epithets like "mearsmear nose", "foot-sore wanderings". Most simple and trite epithets were rendered as epithets while the author's epithets were often translated by descriptive translation means.

But in many cases translators refer to replacing epithets with similes. For example, the original "beryl-green eyes" [13, 29] 
was translated by Ye. Chistiakova-Ver like "зеленые, точно берилль, глаза" [8, 234]; by N.Giliarovska like "яркие изумрудные глаза" [7, 251].

Such replacements were predetermined by more strict compatibility norms in translation language (Russian) as compared to English. In our opinion, the following translation technique was employed in accordance with the translation re-addressing strategy and preconditioned by the need for adaptation. The main conclusion is that the author's message was preserved through the associative field identity. All the suggested translation variants may be considered adequate despite the qualitative replacements. The occasional author's epithets dominance predetermined the neologisms high percentage.

Another stylistic device replacement example is given below. R. Kipling: "gathered in the supple cable-like neck" [19, 212]. Ye. Chistiakova-Ver: "съежсился на упругой, похожей на канат шее" [8, 336]. N. Giliarovska: "обхватил гибкую, как канат, шею" [7, 363].

As for the rendering metaphors difficulties, there were outlined about 36 metaphor cases. All metaphoric units were subdivided into the following groups according to the translation technique. Metaphors translated with the image preservation- 70\%; metaphors translated by replacing the image $-8 \%$; and demetaphorization cases $-22 \%$ which also illustrate the neutralization technique.

R. Kipling: "...nerves were steel and muscles were iron..." [19, 203].Ye. Chistiakova-Ver:"... нервы были тверды, как сталь, а мускулы крепки, как железо..." [8, 329]. N. Giliarovska: "...со стальными нервами и железныли мускулами..." [7, 356].

Translating into Russian this type of metaphor, based upon materialization, is not a challenge, as there exist such stereotypical phraseological units as "стальные нервы" and "железные мускулы", which also include epithets. All the translators managed to translate metaphors together with images they conveyed. However, Ye. ChistiakovaVer rendered the metaphor by simile means, thus, in our opinion, reducing the expressiveness effect.

R. Kipling: "Thou hast untied the feet of Death." [19, 24]. Ye. Chistiakova:

"Tы снял nуты с ног смерти" [8, 193]. N. Giliarovska: "Ты развязал ноги Смерти" [7, 206].

As it is a well-known fact, there is an idiom in Russian "развязать руки", which means to give somebody freedom to act. And this meaning is easily derived from the context: "Thou hast untied the feet of Death. [...] Thou hast taught Man to kill!" In our opinion, the lexeme "ноги" should have been replaced in translation for "руки", and thus the association of both the direct and indirect meaning had been preserved. In this case like in the following example the metaphor translation was performed by word-for-word translation which resulted in the metaphorization loss. R. Kipling: "Anger is the egg of Fear" [19, 274]. N. Giliarovska:

"Страх рождает гнев и смерть..." [7, 412].

One of the distinctive "Just so Stories" features is the occasional coinages abundance which pose certain difficulties in their adequate rendering aspect in Russian. Some apt translations examples byword-for-word translation means and descriptive translation are given below.

R. Kipling: "...a man of infinite-resourceand-sagacity...[19, 34]. Ye. Chistiakova:"...он необыкновенно умен и находчив..." [9, 178]. K. Chukovski:

"...этот человек очень находчивый, умный и храбрый..." [11,1 1].

R. Kipling: "...a wait-a-bit thornbush..."[19, 75]. Ye. Chistiakova: "...в середине тернового куста, который как бы говорил: "Погоди, погоди" [9, 206]. К. Chukovski:"... колючем терновнике..." [11, 51]. V. Pozner: "...в середине колючего непролазного куста..." $[12,11]$.

R. Kipling:"...this befell and behappened..." [19, 182]. Ye. Chistiakova: "..все ... произошло и случилось..." [9, 207]. K. Chukovski: "...это произочло..." [11, 153].V. Pozner:"...рассказ пойдёт..." [12, 26$].$

The stylistic devices rendering translation techniques analysis in R. Kipling's tales in "The Jungle Book" and "The Second Jungle Book" such as personification (23 units), hyperbole (22 units) and periphrasis (20 units) were mostly trancfered fully, though sometimes with partial omissions. So, Ye. Chistiakova-Ver preserved about $91 \%$ of all the personification cases, N. Daruzes $-78 \%$, and N. Giliarovska $-70 \%$. In total there were preserved about $85 \%$ cases of hyperbole and $75 \%$ periphrasis cases.

Conclusions and perspectives. The main research conclusions are the following. The dominant translation, rendering the uniqueness, strategies in R. Kipling's style are respectively the communicatively relevant translation strategy and the re-addressing strategy. The main translation techniques are: stylistic device replacement, descriptive translation, word-for-word translation, in rare cases omission due to the translation neutralization tactic. 
The main challenges for translators of R. Kipling's fairy tales are occasional coinages, onomaetopoeic words and the author's unique metaphors and epithets, revealing the writer's individual style. The main translating problems of R. Kipling's prose into Russian include: on the phonological level - the pronunciation peculiarities and graphical presentation, on the lexical level - the differences in tropes and associative field of phraseological units; on the morphological level - the typological distinctive features of the main speech and paradigms parts; on the syntactical level - the sentence types peculiarities, communicative types and sentence members functions.

\section{ЛIТЕРАТУРА}

1. Бобылев Б.Г. Культура речи и стилистика: учебное пособие. Орел: Орел ГТУ, 2003. 132 с.

2. Брауде Л.Ю. К истории понятия «Литературная сказка». Известия АН СССР Серия литературы и языка. 1977. T. 36. № 3. С. 234.

3. Гальперин И.Р. Стилистика английского языка: Учебник (на английском языке). Изд. стереотип. М.: Книжный дом «ЛИБРОКОМ». 2017. $336 \mathrm{c}$.

4. Казакова T.A. Translation Techniques. Практические основы перевода. СПб.: «Издательство Союз». 2001. 320 с.

5. Казакова Т.А. Художественный перевод: учебное пособие. СПб.: ИВЭСЭП. Знание. 2002. 112 с.

6. Киплинг Р. Книги джунглей: сб.: пер. с англ. М.: АСТ: МОСКВА: ХРАНИТЕЛЬ, 2006. 412 с.

7. Киплинг Р. Собрание сочинений: В 6 т. Т. 3: Предисловие автора; Первая книга джунглей. Вторая книга джунглей / Пер. с англ. Е. Чистяковой-Вэр; В горной Индии: Рассказы / Пер. с англ. Е. Киселева. М.: ТЕРРА. Книжный клуб. 2007. 528 с.

8. Киплинг Р. Собрание сочинений: В 6 т. Т. 4: Рикша-призрак: Рассказы / Пер. с англ. Е. Нелидовой; Сказки и легенды / Пер. с англ. Е. Чистяковой- Вэр; Труды дня: Рассказы / Пер. с англ. А. Репиной. М.: ТЕРРА. Книжный клуб. 2007. 512 с.

9. Киплинг Дж. Р. Книга джунглів / Пер. с англ.М.: Махаон. Азбука-Аттикус. 2014. 224 с.

10. Киплинг Дж. Р. Сказки / Пер. с англ. К. Атаровой, Н. Голя, С. Маршака, Р. Померанцевой, К. Чуковского, Я. Шапиро / Худож. Р. Ингпен. М.: Махаон. 2015. 192 с.

11. Киплинг Р.Рассказы просто так в переводе В. Познера. М.: АСТ. 2015. 112 с.

12. Киплинг Р. Книга Джунглей: сборник рассказов на англ. языке. М.. Т8. 2016. 320 с.

13. Комиссаров В.Н. Теория перевода (лингвистические аспекты): учеб. для ин-тов и фак. иностр. яз / В.Н. Комиссаров. М.: Высш. шк.1990. 253 с.

14. Кухаренко В.А. Практикум по стилистике английского языка. Seminars in Stylistics: учеб. пособие. М.: Флинта. 2016. 184 с.

15. Нелюбин Л.Л. Лингвостилистика современного английского языка: учеб. пособие. М.: Флинта: Наука. 2007. $128 \mathrm{c}$.

16. Прозоров В. Г. Основы теории и практики перевода с английского языка на русский. Петрозаводск: КГУ. 1998. $234 \mathrm{c}$.

17. Сдобников В.В. Теория перевода: учебник для студентов лингвистических вузов и факультетов иностранных языков / В. В Сдобников, О.В Петрова. М.: АСТ: Восто - Запад, 2007. 448 с.

18. Солганик Г.Я. Стилистика текста: учеб. пособие для студентов, преподавателей- филологов, аспирантов. М.: Флинта: Наука. 1997. 253 с.

19. Kipling R. Just so Stories. M.: Progress Publishers, 1972. 254 c.

\section{REFERENCES}

1. Bobyilev B.G. (2003). Kultura rechi i stilistika: Uchebnoe posobie. [Speech culture and stylistics]. Orel: Orel GTU [in Russian].

2. Braude L.Yu. (1977). K istorii ponyatiya "Literaturnaya skazka" // Seriya literaturyi i yazyika. [On the origin of the concept "literary tale"]. [in Russian].

3. Galperin I.R. (2017). Stilistika angliyskogo yazyika: Uchebnik. [Stylistics. Textbook]. Moscow. [in English].

4. Kazakova T.A. (2001). Translation Techniques. Prakticheskie osnovyi perevoda. [Practical translation fundamentals]. $\mathrm{SPb}$. [in Russian].

5. Kazakova T.A. (2002). Hudozhestvennyiy perevod: Uchebnoe posobie. [Artistic translation]. SPb. [in Russian].

6. Kipling R. (2006). Knigi dzhungley. [The Jungle Books]. Moscow. [in Russian].

7. Kipling R. (2007). Sobranie sochineniy. Pervaya kniga dzhungley. Vtoraya kniga dzhungley. [Collection of works. "The First Jungle Book", "The Second Jungle Book"]. Moscow. [in Russian].

8. Kipling R. (2007). Sobranie sochineniy. Riksha-prizrak: Rasskazyi; Skazki i legendyi / Per. s angl. E. ChistyakovoyVer. [Collection of works. Rickshaw ghost. Short stories; Tales and legends]. Moscow. [in Russian]. 
9. Kipling R. (2014) Kniga dzhungley: Per. s angl. [The Jungle Book]. Moscow. [in Russian].

10. Kipling R. (2015). Skazki: Per. s angl. K. Atarovoy, N. Golya, S. Marshaka, R. Pomerantsevoy, K. Chukovskogo, Ya. Shapiro. [Tales]. [in Russian].

11. Kipling R.(2015). Rasskazyi prosto tak v perevode V. Poznera. [Just So Stories translated by V. Pozner]. Moscow. [in Russian].

12. Kipling R. (2016). Kniga Dzhungley: sbornik rasskazov na angl. yazyike. [Collection of short stories in English]. [in Russian].

13. Komissarov V.N. (1990). Teoriya perevoda (lingvisticheskie aspektyi). [Translation theory (linguistic aspects)]. Moscow. [in Russian].

14. Kuharenko V.A. (2016). Praktikum po stilistike angliyskogo yazyika. [Seminars in Stylistics]. Moscow. [in English].

15. Nelyubin L.L. (2007). Lingvostilistika sovremennogo angliyskogo yazyika. [Linguostylistics of the modern English language]. Moscow. [in Russian].

16. Prozorov V. G. (1998). Osnovyi teorii i praktiki perevoda s angliyskogo yazyika na russkiy. [The fundamentals of the theory and practice of translation from English into Russian]. Petrozavodsk. [in Russian].

17. Sdobnikov V.V. (2007). Teoriya perevoda: (uchebnik dlya studentov lingvisticheskih vuzov i fakultetov inostrannyih yazyikov) / V. V Sdobnikov, O.V Petrova. [The translation theory: (textbook for students of linguistic educational institutions and faculties of foreign languages]. Moscow. [in Russian].

18. Solganik G.Ya. (1997). Stilistika teksta: ucheb. posobie dlya studentov, prepodavateley- filologov, aspirantov / G.Ya. Solganik. [Text stylistics: textbook for students, teachers-philologists, aspirants]. Moscow. [in Russian].

19. Kipling R. (1972). Just so Stories. Moscow. [in English].

\title{
ДО ПРОБЛЕМИ ВІДТВОРЕННЯ ІНДИВІДУАЛЬНОГО СТИЛЮ РЕД’ЯРДА КІПЛІНГА У ПЕРЕКЛАДІ
}

\author{
Попелюк Вікторія Павлівна \\ викладач кафедри іноземних мов \\ Військової академії (м. Одеса) \\ вул. Фонтанська дорога, 10, Одеса, Україна
}

Статтю присвячено вивченню специфіки перекладу прози Р. Кіплінга російською мовою. Дослідження спрямоване на визначення особливостей індивідуального стилю Редьярда Кіплінга, шуо знайшли своє відображення у його славетних літературних казках.

Метою дослідження є визначення можливих труднощів перекладу казок $P$. Кіплінга та різних способів подолання ичих проблем за рахунок прийомів перекладу. Дослідження проводиться на матеріалі оригінальних англійських казок та їх перекладів російською. За допомогою порівняльного аналізу відібрано найбільш адекватні варіанти перекладу та вдалі прийоми. Головними критеріями якісного перекладу є адекватність, точність $i$ еквівалентність.

Було зроблено висновок, щ⿻о провідними перекладацькими стратегіями $\epsilon$ стратегія комунікативно релевантного перекладу та стратегія переадресаиії. Як було підтверджено експериментально, головними задіяними прийомами перекладу виявились відповідно заміна і описовий переклад. Найбільщі труднощі у переклад $i$ викликають стилістичні засоби, оказіоналізми, слова-зрощення, так само й як випадки звуконаслідування та порушення семантичного зв'язку. Оригінальні тексти насичені авторськими новоутвореннями, більшість із яких були майстерно відтворені перекладачами.

Кількісні параметри розподілу стратегій, тактик і прийомів перекладу виявили типологічну спільність задіяних операцій. Було визначено кореляиію прийому деметафоризаиії та тактики лінгвокультурної адаптації.

Перспектива вивчення варіативності стратегій, тактик і прийомів у перекладі прози Р. Кіплінга різними мовами вбачається у дослідженні дистинктивних параметрів перекладацьких стратегій $i$ тактик та у застосуванні порівняльного аналізу на основі задіяних мов.

Ключові слова: індивідуальний стиль, прийом перекладу, адекватність, почність, еквівалентність. 